\title{
Insights into the Microstructure of Hydrothermal Synthesized Nanoscale $\mathrm{K}_{2} \mathrm{O}-\mathrm{Al}_{2} \mathrm{O}_{3}-\mathrm{SiO}_{2}-\mathrm{H}_{2} \mathrm{O}$ Particles
}

\author{
Bao Liu ${ }^{1,2,3}$, Chunyan Zhu ${ }^{1,2}$, Kunde Zhuang ${ }^{1,2}$, Le Shuai ${ }^{1,2}$, Dongxu Li ${ }^{1,2,3}$, Wujian Long ${ }^{1,2}($, \\ Feng Xing ${ }^{1,2}$ and Yuan Fang ${ }^{1,2, *(\mathbb{D})}$ \\ 1 College of Civil and Transportation Engineering, Shenzhen University, Shenzhen 518060, China; \\ baoliu@njtech.edu.cn (B.L.); zcy243003@163.com (C.Z.); vensen2261109@foxmail.com (K.Z.); \\ 1810332025@email.szu.edu.cn (L.S.); dongxuli@njtech.edu.cn (D.L.); longwj@szu.edu.cn (W.L.); \\ xingf@szu.edu.cn (F.X.) \\ 2 Guangdong Provincial Key Laboratory of Durability for Marine Civil Engineering, Shenzhen 518060, China \\ 3 Jiangsu National Synergetic Innovation Center for Advanced Materials (SICAM), Nanjing Tech University, \\ Nanjing 210009, China \\ * Correspondence: yuanfang@szu.edu.cn; Tel./Fax: +86-755-2653-4021
}

Received: 28 November 2019; Accepted: 24 December 2019; Published: 26 December 2019

\begin{abstract}
K-A-S-H $\left(\mathrm{K}_{2} \mathrm{O}-\mathrm{Al}_{2} \mathrm{O}_{3}-\mathrm{SiO}_{2}-\mathrm{H}_{2} \mathrm{O}\right)$ gel is a key phase that forms in most alkali-activated binders (eco-friendly binders which utilize a substantial amount of industrial by-product). An in-depth understanding of the microstructure and performance of this nano-sized key phase facilitates better application to alkali-activated binders. However, such studies remain little and undetailed. Therefore, our research aims to provide insights into the microstructure of K-A-S-H particles synthesized with accurate stoichiometric control by the hydrothermal method through thermogravimetric analysis (TG), Fourier transform infrared spectroscopy (FTIR), nuclear magnetic resonance (NMR), scanning electron microscopy (SEM), transmission electron microscopy (TEM) and BET surface area. The results show that for materials prepared at the curing temperature lower than $80^{\circ} \mathrm{C}$, the K-A-S-H products were completely amorphous. With increased curing temperature and time, the K-A-S-H products were transformed from the amorphous phase to the crystalline zeolite phase structure, with a reduction in the specific surface area. The TG results indicate that the crystalline phase contains more non-evaporated water or zeolite water for structural rearrangement. The degree of tetrahedral polymerization slightly decreased with an increase of the $\mathrm{K}_{2} \mathrm{O} / \mathrm{SiO}_{2}$ ratio as the amount of non-bridged oxygen atoms increased, whereas it gradually increased with an increase of curing temperature and time, as suggested by the FTIR and NMR results. Various $\mathrm{K}_{2} \mathrm{O} / \mathrm{SiO}_{2}$ ratios resulted in the formation of zeolite K-H and K-G zeolite, both of which exhibited highly polymerized three-dimensional network structures. However, there was no significant effect of the $\mathrm{SiO}_{2} / \mathrm{Al}_{2} \mathrm{O}_{3}$ ratio on the structure of $\mathrm{K}-\mathrm{A}-\mathrm{S}-\mathrm{H}$ products. Overall, these results provide insight into understanding the chemical stability of K-A-S-H.
\end{abstract}

Keywords: K-A-S-H; zeolite; nuclear magnetic resonance; polymerization degree; phase composition

\section{Introduction}

The increasing demand for low-cost and durable construction materials has stimulated the study of alternative cementitious binders [1]. Alkali-activated binders have been widely discussed and promoted. These binders are promising cementitious materials that can be used in place of Portland cement (PC) in many applications, including concrete. Compared with Portland cement-based production, the use of alkali-activated materials can reduce related carbon dioxide emissions by more 
than $80 \%$ [2,3], an important concern worldwide. At the same time, this research is important for the reuse of solid waste. The properties of alkali-activated binders are dependent on the type of gel that dominates the structure, which is largely determined by the calcium content in the system. A primary reaction product of alkali-activated binder systems may be an alkali aluminosilicate-type gel [4], a gel type that is poor in calcium. This gel is often represented as hydrated sodium aluminosilicate $\mathrm{N}-\mathrm{A}-\mathrm{S}-\mathrm{H}\left(\mathrm{N}_{2} \mathrm{O}-\mathrm{Al}_{2} \mathrm{O}_{3}-\mathrm{SiO}_{2}-\mathrm{H}_{2} \mathrm{O}\right)$ or, with substitution of potassium for sodium, $\mathrm{K}-\mathrm{A}-\mathrm{S}-\mathrm{H}\left(\mathrm{K}_{2} \mathrm{O}-\mathrm{Al}_{2} \mathrm{O}_{3}-\mathrm{SiO}_{2}-\mathrm{H}_{2} \mathrm{O}\right)$ [5]. This nomenclature describes the chemical nature of the reaction product rather than its precursor, similar to the designation of C-S-H $\left(\mathrm{CaO}-\mathrm{SiO}_{2}-\mathrm{H}_{2} \mathrm{O}\right)$ [6].

Despite the promising qualities of these materials, the use of alkali-activated materials in the construction industry remains limited, partly because of the complex and volatile chemical composition of wastes. Additionally, because by-product materials are used as the main precursors, it is difficult to achieve reproducibility and accurate stoichiometry of the main hydration products formed in these systems. To solve these problems, a better understanding of the reaction mechanism of the alkali-activated binder system is required. For this reason, many recent studies have explored the artificial synthesis of gels with pre-designed compositions. Our previous research [3,4,7] performed the hydrothermal synthesis of C-A-S-H $\left(\mathrm{CaO}-\mathrm{Al}_{2} \mathrm{O}_{3}-\mathrm{SiO}_{2}-\mathrm{H}_{2} \mathrm{O}\right)$ and $\mathrm{N}-\mathrm{A}-\mathrm{S}-\mathrm{H}$ and showed that with a controlled composition of raw materials, the resulting product has high purity and is similar in composition with alkali-activated product gel. The temperature and curing time are important factors determining the characteristics of the prepared materials, resulting in different microstructure and performance of alkali-activated cementitious material hydration products. Walkley et al. [2] also demonstrated the production of stoichiometrically controlled N-A-S-H gels via alkali-activation of high-purity synthetic amorphous aluminosilicate powders, providing an innovative process to accurately simulate the chemistry of alkali-activated cementitious materials. Constructed models based on those for zeolite, primarily related to analcime, were also proposed, in which assumes that the (N, K)-A-S-H gel is amorphous and has a randomly distributed cluster reciprocal structure with short-range order of $\mathrm{SiO}_{4}$ tetrahedron and $\mathrm{AlO}_{4}$ octahedron [8,9]. However, it was argued that in the N-A-S-H structure, both $\mathrm{Si}$ and $\mathrm{Al}$ exist in the form of coordinated tetrahedrons, whereas $\mathrm{Si}$ is mainly in the $\mathrm{Q}_{4}(\mathrm{mAl})$ environment with the $\mathrm{m}$ value depending on the $\mathrm{Si} / \mathrm{Al}$ in the structural composition $[10,11]$. Additionally, the N-A-S-H chemical composition is similar to the hydrothermal synthesis of zeolite, with a structure that is characterized by short-range order. Sol-gel synthesis method was also adopted [12] and a model was established in which colloids can form crosslinks to fabricate a three-dimensional network structure. The use of an $\mathrm{Al}_{2} \mathrm{O}_{3} / \mathrm{K}_{2} \mathrm{O}$ ratio of 1.0 is required because certain other ions must be used to offset the electrical imbalance in the structure when $\mathrm{Al}^{3+}$ ions replace the $\mathrm{Si}^{4+}$ ions in the polymer. These studies $[10,11,13,14]$ on the structural composition and synthesis of N-A-S-H gel revealed a three-dimensional network structure formed by a common oxygen atom between an aluminoxy tetrahedron and a siloxane tetrahedral structural unit. The cavity formed inside the three-dimensional network structure can be filled with the equilibrium structural charge of the alkali metal cations, $\mathrm{Na}^{+}$or $\mathrm{K}^{+}$.

However, the location of alkali metal cations in gels or the retention mechanisms involved were not completely resolved in the above-mentioned studies. Although both K-A-S-H and N-A-S-H are hydration products of low-calcium alkali-activated materials, the differences in the solvated ionic radius and enthalpy for the hydration of $\mathrm{K}$ and $\mathrm{Na}$ cause these materials to exhibit different affinities for negatively charged surfaces [15-17]. These different affinities cause a large difference in the chemical composition and structure of the resulting gel. Little is known about the synthesis and performance characterization of K-A-S-H-based nanogels. Thus, the goal of this work was to evaluate the chemical composition and structure of K-A-S-H gels and explore the state of $\mathrm{Al}$ in the inner structure of these gels.

In this study, the products of potassium aluminosilicate formed under hydrothermal conditions include aluminosilicate gel or zeolite. The products were characterized by Fourier transform infrared spectroscopy (FTIR), thermogravimetric analysis (TG), scanning electron microscopy (SEM), and transmission electron microscopy (TEM). Unfortunately, due to the poor crystallization of most gel 
phases, X-ray diffraction (XRD) cannot provide structural information. As an alternative, we adopted advanced characterization techniques, including ${ }^{27} \mathrm{Al},{ }^{29} \mathrm{Si}$ magic angle spinning-nuclear magnetic resonance (MAS-NMR) analysis of atomic coordination and polyhedral polymerization in crystalline and amorphous materials. The results from this work approximately reflect the changes in the composition and structure of hydration products in the alkali-activated cementitious materials due to temperature, time, and the composition of the raw materials. These findings can approximately reflect the changes in the composition and structure of the alkali-activated binders under various synthetic conditions and can provide a better understanding of the phase transformations and microstructure development of alkali-activated cementitious materials.

\section{Experimental Procedure}

\subsection{Materials}

Nano- $\mathrm{SiO}_{2}(50 \pm 5 \mathrm{~nm})$ and nano- $\mathrm{Al}_{2} \mathrm{O}_{3}(\gamma$-phase, $10 \mathrm{~nm})$ were purchased from Macklin Biochemical Co., Ltd. (Shanghai, China). Potassium hydroxide $(\mathrm{KOH})$ and anhydrous ethanol were obtained from Xilong Scientific Co., Ltd. (Guangdong, China). Deionized water was used to synthesize K-A-S-H. All materials were of analytical reagent (A.R.) grade.

\subsection{Synthesis of $K-A-S-H$}

The proportions of nano- $\mathrm{SiO}_{2}$, nano- $\mathrm{Al}_{2} \mathrm{O}_{3}, \mathrm{KOH}$, and deionized water are shown in Table 1 . Nanoscale K-A-S-H gel was synthesized according to our previous hydrothermal method $[3,4]$. The samples are named as follows: using K-A-S-H1.0 $-1 \mathrm{~d}-95$ as an example, the K-A-S-H1.0 indicates a $\mathrm{K}_{2} \mathrm{O} / \mathrm{SiO}_{2}$ ratio in the K-A-S-H system of 1.0 , the subscript indicates a $\mathrm{SiO}_{2} / \mathrm{Al}_{2} \mathrm{O}_{3}$ ratio of 1 , the $1 \mathrm{~d}$ indicates a curing time of 1 day, and the 95 indicates that the material was cured at a temperature of $95^{\circ} \mathrm{C}$.

Table 1. Mixing proportions used to prepare $\mathrm{K}_{2} \mathrm{O}-\mathrm{Al}_{2} \mathrm{O}_{3}-\mathrm{SiO}_{2}-\mathrm{H}_{2} \mathrm{O}(\mathrm{K}-\mathrm{A}-\mathrm{S}-\mathrm{H})$.

\begin{tabular}{cccc}
\hline Sample & $\mathbf{K}_{\mathbf{2}} \mathbf{O} / \mathbf{S i O}_{\mathbf{2}}$ & $\mathbf{S i O}_{\mathbf{2}} / \mathbf{A l}_{\mathbf{2}} \mathbf{O}_{\mathbf{3}}$ & Water/Solid Ratio \\
\hline $\mathrm{K}-\mathrm{A}-\mathrm{S}-\mathrm{H} 1.0_{1}$ & 1.0 & 1.0 & 5.0 \\
$\mathrm{~K}-\mathrm{A}-\mathrm{S}-\mathrm{H} 2.0_{1}$ & 2.0 & 1.0 & 5.0 \\
$\mathrm{~K}-\mathrm{A}-\mathrm{S}-\mathrm{H} 0.5_{2}$ & 0.5 & 2.0 & 5.0 \\
$\mathrm{~K}-\mathrm{A}-\mathrm{S}-\mathrm{H} 1.0_{2}$ & 1.0 & 2.0 & 5.0 \\
$\mathrm{~K}-\mathrm{A}-\mathrm{S}-\mathrm{H} 2.0_{2}$ & 2.0 & 2.0 & 5.0 \\
\hline
\end{tabular}

\subsection{Characterization of Samples}

The XRD patterns of K-A-S-H powder were obtained on a Brucker D8 Advance X-ray diffractometer (Brucker, Karlsruhe, Germany). Thermogravimetric analysis of K-A-S-H powder was performed using a Perkin Elmer Diamond instrument (Boston, MA, USA). The polymerization state analyses utilized the techniques of Fourier transform infrared (FTIR, PerkinElmer, Boston, MA, USA) and ${ }^{29} \mathrm{Si},{ }^{27} \mathrm{Al}$ solid-state MAS-NMR. The morphology analyses were performed using scanning electron microscopy (SEM, FEI Company, Hillsboro, OR, USA) and transmission electron microscopy (TEM, JEOL, Tokyo, Japan). A DelsaMax CORE nanolaser particle size analyzer (Beckman Coulter, Shanghai, China) was used to determine the particle size distribution of K-A-S-H samples.

\section{Results and Discussion}

\subsection{X-Ray Diffraction Analysis}

Figure 1 shows the XRD patterns of the K-A-S-H samples. At $25{ }^{\circ} \mathrm{C}, 60^{\circ} \mathrm{C}$, and $80^{\circ} \mathrm{C}$ curing temperature, all the prepared $\mathrm{K}-\mathrm{A}-\mathrm{S}-\mathrm{H}$ products appeared completely amorphous. $\mathrm{The}_{2} \mathrm{O} / \mathrm{SiO}_{2}$ ratio and curing time had no significant effect on the crystallinity of the samples, as shown in Figure $1 \mathrm{a}$. 
In addition, a broad featureless hump caused by amorphous aluminosilicate was observed between $25^{\circ}$ and $35^{\circ} 2 \theta$ [4]. As the curing temperature increased to $95^{\circ} \mathrm{C}$, all K-A-S-H products remained amorphous at the 1-day age. When the curing time reached 3 days for K-A-S-H1.02-3d-95, crystalline phases first appeared, though the crystallinity of the K-A-S-H samples prepared using other $\mathrm{K}_{2} \mathrm{O} / \mathrm{SiO}_{2}$ ratios was still very poor. When the curing time was extended to 7 days, all K-A-S-H samples were transformed into the crystalline state, as shown in Figure 1b. Specifically, The XRD pattern (see Figure 1b) of the crystal phase formed by K-A-S-H0.52-7d-95 closely matched that of zeolite K-H, with PDF\#16-0692, $\mathrm{K}_{2} \mathrm{Al}_{2} \mathrm{Si}_{4} \mathrm{O}_{12} \bullet x \mathrm{H}_{2} \mathrm{O}$, Si:Al:K = 2:1:1, which is classified as an unknown structure type. Similar results were also reported by Sathupunya et al. [18] and Liu et al. [19]. In addition, K-G zeolite $\left(\mathrm{K}_{2} \mathrm{Al}_{2} \mathrm{SiO}_{6} \bullet \mathrm{H}_{2} \mathrm{O}\right.$, PDF\#12-1094) [20] crystalline phase was observed in the sample K-A-S-H2.02-7d-95, and weak diffraction peaks of zeolite K-H and K-G zeolite were observed in sample K-A-S-H1.02-3d-95. With an increase of curing time, the degree of crystallinity increased. This may be attributed to the difference in the crystalline structure and category of the zeolite phase induced by the difference in $\mathrm{K}_{2} \mathrm{O}$ content. Yuan et al. [20] found that zeolite $\mathrm{K}-\mathrm{H}$ is a stable phase at lower concentrations of $\mathrm{KOH}$, and $\mathrm{K}-\mathrm{G}$ zeolite is more stable at relatively higher concentrations of $\mathrm{KOH}$. In summary, $\mathrm{K}^{+}$and $\mathrm{OH}^{-}$ are the dominant influence factors controlling the types of zeolite formed in the products. However, as shown in Figure $1 \mathrm{c}, \mathrm{SiO}_{2} / \mathrm{Al}_{2} \mathrm{O}_{3}$ ratios had no significant effect on the crystallinity of the products. Moreover, the product $\mathrm{X}$-ray diffraction pattern at $95^{\circ} \mathrm{C}$ for material aged for 3 days showed a hump at $2 \theta$ of $25-35^{\circ}$, similar to the amorphous hump and low crystalline phase seen for $(\mathrm{N}, \mathrm{K})-\mathrm{A}-\mathrm{S}-\mathrm{H}$ gels $[21,22]$.

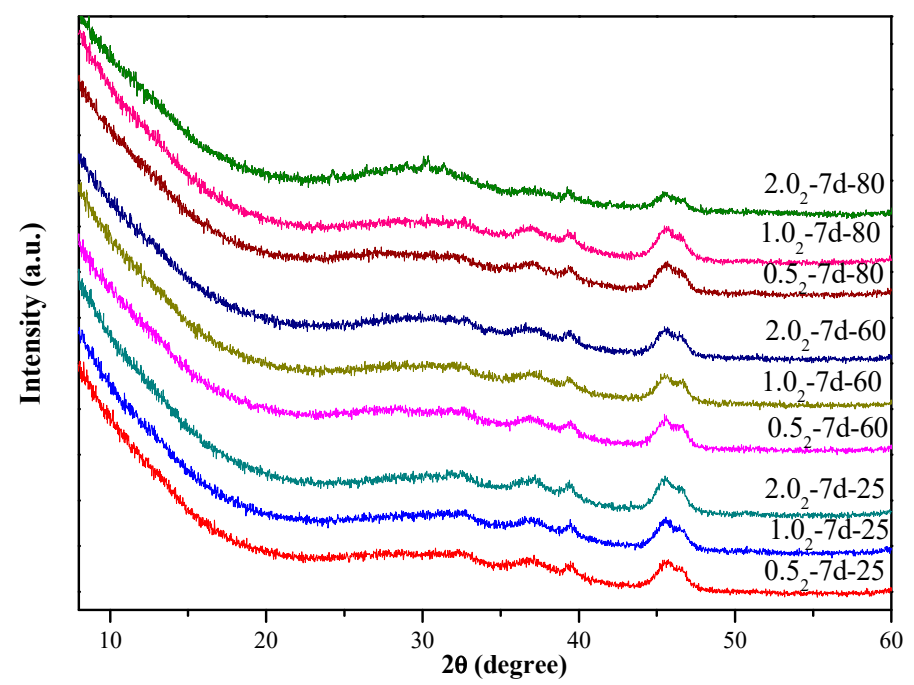

(a)

Figure 1. Cont. 


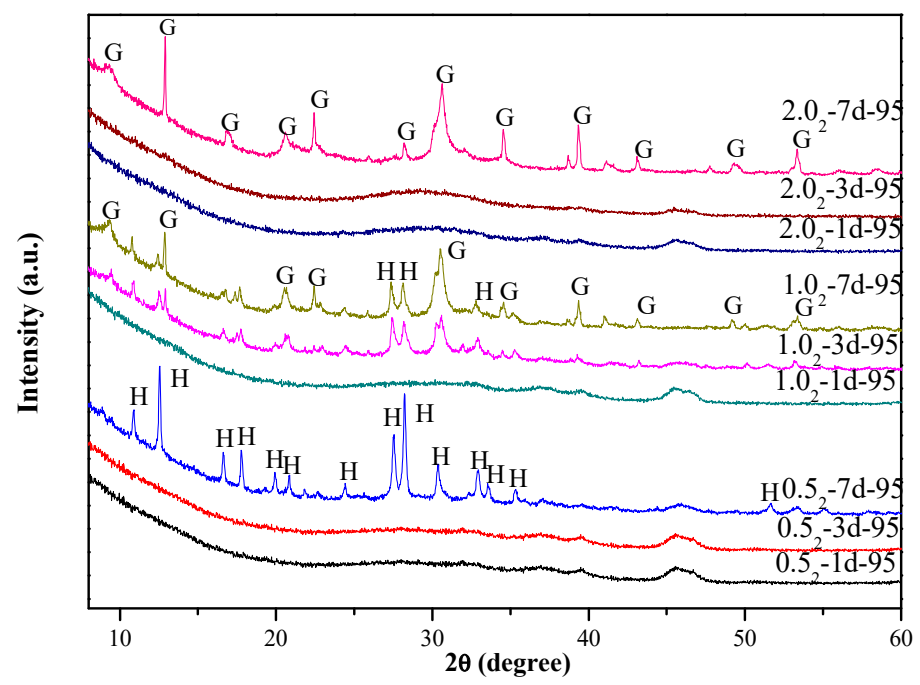

(b)

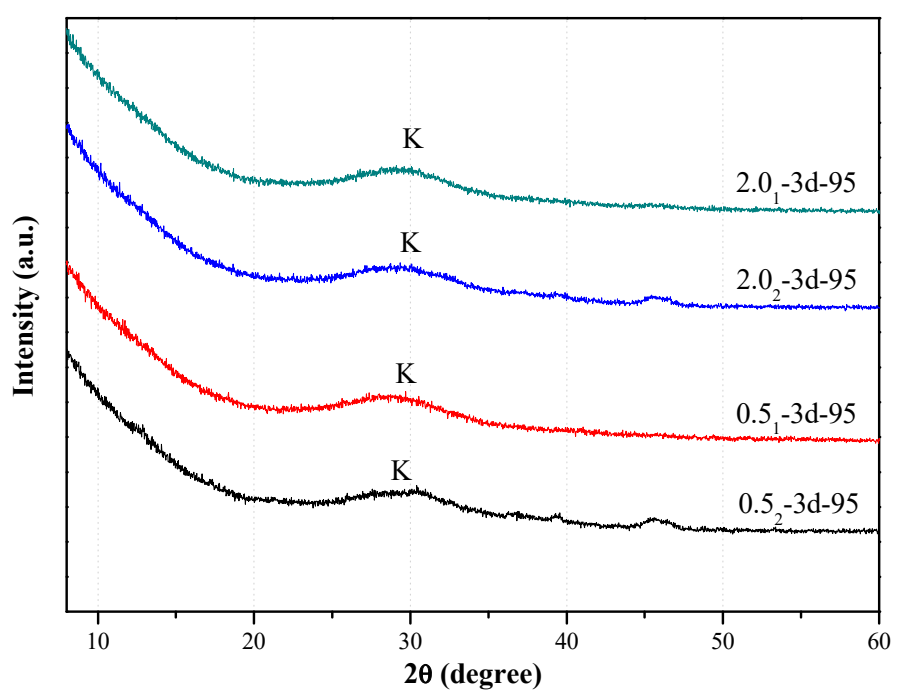

(c)

Figure 1. X-ray diffraction (XRD) patterns of K-A-S-H samples (a) synthesized at different reaction temperatures, (b) synthesized by reaction at $95{ }^{\circ} \mathrm{C}$, and (c) synthesized using different $\mathrm{SiO}_{2} / \mathrm{Al}_{2} \mathrm{O}_{3}$ ratios at $95^{\circ} \mathrm{C}$. (K: K-A-S-H gels, G: K-G zeolite, H: Zeolite K-H).

\subsection{Thermogravimetric Analysis}

The TG/DTG curves of the K-A-S-H samples are shown in Figure 2. In general, each K-A-S-H powdery sample showed a mass loss below $150^{\circ} \mathrm{C}$. This mass loss value was related to changes in the amount of water adsorbed or evaporated [23] during synthesis. There was a large mass loss for sample K-A-S-H2.0 $0_{2}-7 \mathrm{~d}-60$, suggesting high adsorbed water content due to incomplete reaction of the raw materials of the sample under the curing condition of $60{ }^{\circ} \mathrm{C}$ (the raw materials were highly hygroscopic [2]). Samples synthesized using three different $\mathrm{K}_{2} \mathrm{O} / \mathrm{SiO}_{2}$ ratios were cured for 7 days at $95^{\circ} \mathrm{C}$, and the TG/DTG curves showed small mass loss peaks at $190{ }^{\circ} \mathrm{C}, 200^{\circ} \mathrm{C}$, and $250{ }^{\circ} \mathrm{C}$, separately. Combined with the XRD results, the samples contained crystalline zeolite phases, indicating 
more tightly physically bound and/or loss of zeolite water [2,24]. These peaks were not present before 7 days of curing time, which indicates that rearrangement and structural ordering of the water-containing phases (e.g., zeolites) persisted from the 3rd day to the 7th day of curing time as the reaction progressed. Samples K-A-S-H2.0 ${ }_{1}-3 \mathrm{~d}-95$ and K-A-S-H2.02-3d-95 also showed small mass loss peaks at around $200{ }^{\circ} \mathrm{C}$ in the TG/DTG curves, due to the loss of nonevaporable water [23,24], as defined by Thomas et al. $[25,26]$. This can be associated primarily with structural water and some constrained water in the gel.

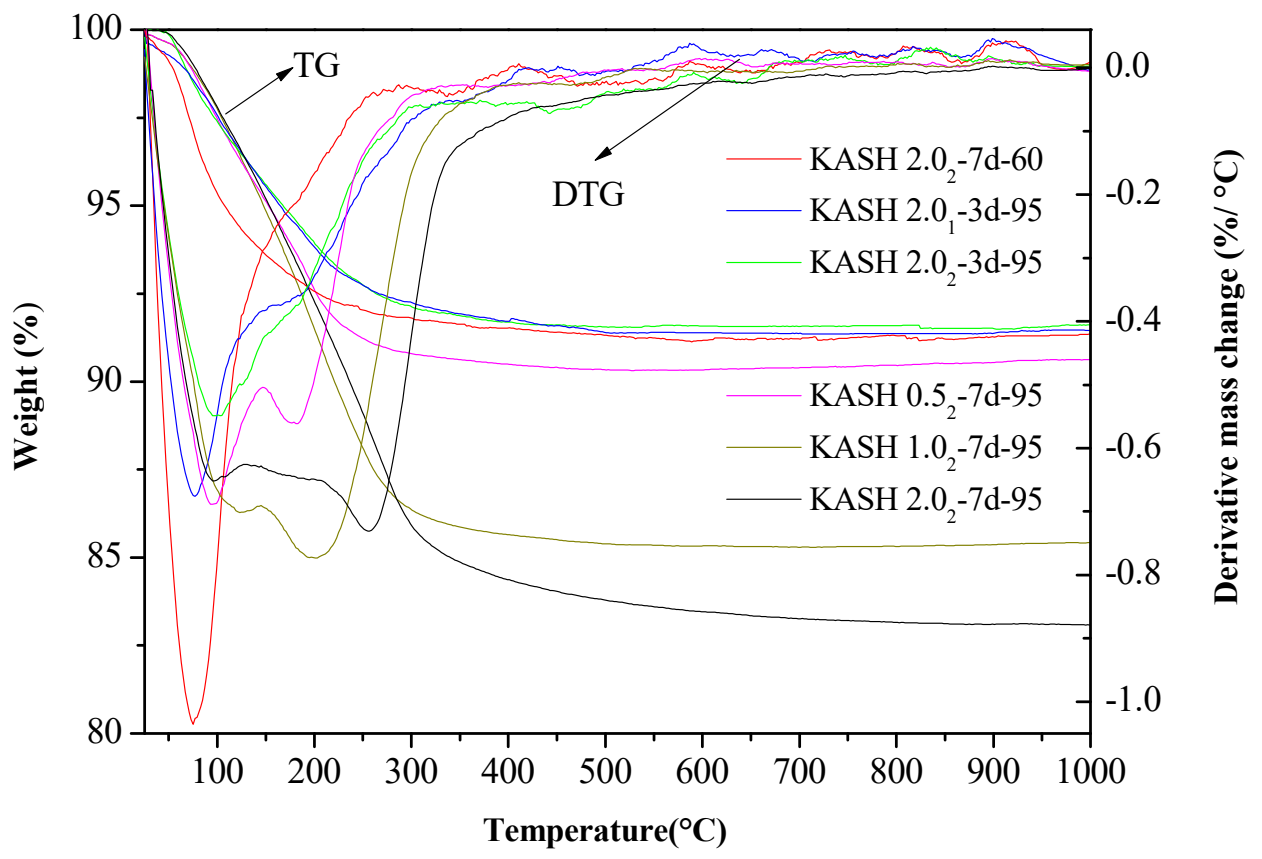

Figure 2. TG/DTG curves of K-A-S-H samples.

As most of the sample was amorphous K-A-S-H, the aforementioned techniques were unable to fully reveal its structural information, especially its main structural unit [SiO4] ${ }^{4-}$ tetrahedron. It is crucial to understand the polymerization process of [SiO4 $]^{4-}$ tetrahedron, as it will provide an understanding of the formation mechanism of the nanostructures of these gels $[20,27,28]$. Therefore, in the next sections, infrared spectroscopy (FTIR) and nuclear magnetic resonance (NMR) were used to study the $[\mathrm{SiO} 4]^{4-}$ tetrahedral anion polymerization state and aluminum coordination state in the K-A-S-H products.

\subsection{Infrared Analysis}

The vibrational spectra of different K-A-S-H samples were determined and are shown in Figure 3. The characteristic bands at $3440 \mathrm{~cm}^{-1}$ and $1640 \mathrm{~cm}^{-1}$ are respectively caused by the stretching vibration and bending vibration of $\mathrm{O}-\mathrm{H}$ in adsorbed water $[29,30]$. The formation of Si-O-T bonds ( $\mathrm{T}=$ tetrahedral $\mathrm{Si}$ or $\mathrm{Al}$ ) results in a strong stretching vibration signal at $1031 \mathrm{~cm}^{-1}$ [2], but this bond is located at about $950 \mathrm{~cm}^{-1}$ in the chain structure of C-(A)-S-H [31]. The K-A-S-H gels show quite different results. The main band (vas T-O: where $\mathrm{T}$ is $\mathrm{Si}$ or $\mathrm{Al}$ ) moves from a low to high wavenumber position, which is more typical in a low calcium environment gel. The characteristic peak of the stretching vibrations of T-O-Si (T Si or Al) bonds is located at about $1031 \mathrm{~cm}^{-1}$ in the K-A-S-H sample at $25{ }^{\circ} \mathrm{C}$, as shown in Figure 3a. With increased curing temperature, this band only slightly shifts to $1021 \mathrm{~cm}^{-1}$. When the curing temperature was increased to $95{ }^{\circ} \mathrm{C}$ (see Figure $3 \mathrm{~b}$ ), this characteristic peak showed a significant shift to $1013 \mathrm{~cm}^{-1}$. This shift was also seen with increased curing time, and this band in sample K-A-S-H2.02-7d-95 shifted to $983 \mathrm{~cm}^{-1}$. The shifts occur with increased silicon substitution by aluminum in the second coordination sphere due to the weaker Al-O bonds [14]. In 
addition, the main bands, corresponding to the $\mathrm{T}-\mathrm{O}-\mathrm{Si}$ ( $\mathrm{T} \mathrm{Si}$ or $\mathrm{Al}$ ) stretching vibrations in the $\mathrm{K}-\mathrm{A}-\mathrm{S}-\mathrm{H}$ samples, became somewhat rounder and broader in shape, particularly after curing at $95^{\circ} \mathrm{C}$ for 7 days. The change of polarization of the oxygen atom on the $\mathrm{Si}-\mathrm{O}-\mathrm{Al}$ linkage, may cause an increase in the remaining $\mathrm{Si}-\mathrm{O}$ bond strength in the previous pairing silicate tetrahedron. This may lead to a higher wavenumber contribution to the main $\mathrm{Si}-\mathrm{O}$ band, thus broadening the band around $983 \mathrm{~cm}^{-1}$ [32]. Comparison of the position of the T-O-Si stretching vibration characteristic peak for different $\mathrm{K}_{2} \mathrm{O} / \mathrm{SiO}_{2}$ ratios reveals band shifts. For materials at the same $\mathrm{SiO}_{2} / \mathrm{Al}_{2} \mathrm{O}_{3}$ ratio, as the $\mathrm{K}_{2} \mathrm{O} / \mathrm{SiO}_{2}$ ratio increased, the band shifted to a low wavenumber. This indicated that an increase in $\mathrm{K}_{2} \mathrm{O} / \mathrm{SiO}_{2}$ ratio causes a decrease in $\mathrm{TO}_{4}$ ( $\mathrm{T}$ is $\mathrm{Si}$ or $\mathrm{Al}$ ) tetrahedral polymerization. These observations are similar to the formation $[2,23,28]$ of the N-A-S-H system product linkages. When $\mathrm{K}_{2} \mathrm{O} / \mathrm{SiO}_{2}$ is increased, the amount of $\mathrm{K}^{+}$in the reaction system exceeded the quantity required to balance the negative charges of $\mathrm{AlO}^{4-}$ tetrahedra. To maintain electric neutrality, the number of non-bridging oxygen bonds with a negative charge in the structure increases. The non-bridging oxygen bonds are not shared by two or more polyhedrons, only connected with a net-forming ion, and the original structure of $\mathrm{TO}_{4}(\mathrm{~T}$ is $\mathrm{Si}$ or $\mathrm{Al})$ becomes more isolated $[2,33,34]$. As a result, the band of Si-O-T stretching vibration moves to a lower wavenumber in the FT-IR spectrum. With increased curing time or temperature, the band appears at a lower wavenumber, indicating that excess $\mathrm{K}^{+}$in the reaction system entered the aluminosilicate structure with an increased reaction degree.

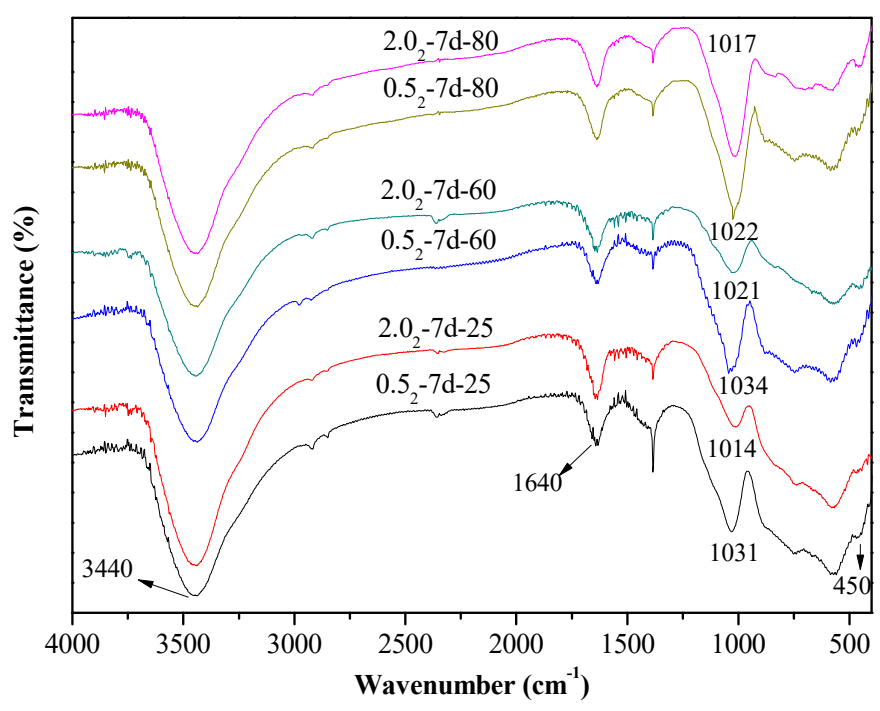

(a)

Figure 3. Cont. 


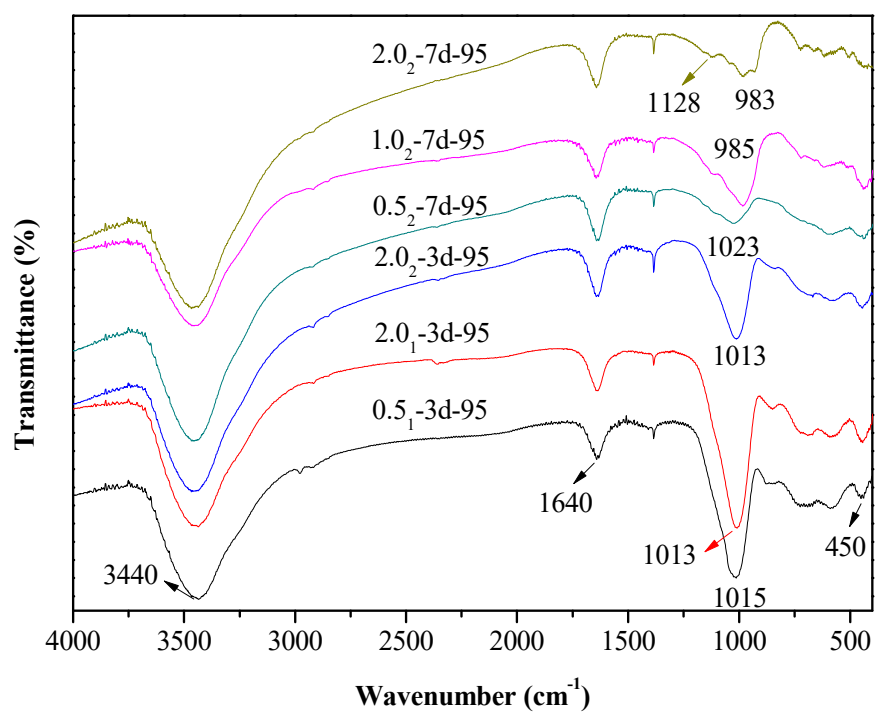

(b)

Figure 3. Fourier transform infrared spectroscopy (FTIR) spectra of K-A-S-H samples (a) synthesized by reaction at temperatures lower than $95^{\circ} \mathrm{C},(\mathbf{b})$ synthesized by reaction at $95^{\circ} \mathrm{C}$.

Additionally, a characteristic peak at $1128 \mathrm{~cm}^{-1}$ was present in the samples cured at $95^{\circ} \mathrm{C}$ for 7 days. This vibrational band at $1128 \mathrm{~cm}^{-1}$ decreased with decreased $\mathrm{K}_{2} \mathrm{O} / \mathrm{SiO}_{2}$ ratio due to the transformation of octahedral $\mathrm{Al}$ to tetrahedral $\mathrm{Al}$ and the formation of $\mathrm{Si}-\mathrm{O}-\mathrm{Al}$ as $\mathrm{Al}$ combined with $\mathrm{Si}-\mathrm{O}-\mathrm{Si}$ [20]. Compared with the $\mathrm{T}-\mathrm{O}-\mathrm{Si}(\mathrm{T}=\mathrm{Si}$ or $\mathrm{Al})$ stretching vibrations in other $\mathrm{K}-\mathrm{A}-\mathrm{S}-\mathrm{H}$ samples, the main bands became somewhat rounder in shape and appeared broader. At constant $\mathrm{K}_{2} \mathrm{O} / \mathrm{SiO}_{2}$ ratio, a change in the $\mathrm{SiO}_{2} / \mathrm{Al}_{2} \mathrm{O}_{3}$ ratio did not significantly change the wavenumber of the characteristic stretching peak of $\mathrm{T}-\mathrm{O}-\mathrm{Si}(\mathrm{T}=\mathrm{Si}$ or $\mathrm{Al}$ ) asymmetric stretching vibration (see Figure $3 \mathrm{~b}$ ), this was consistent with the XRD results and indicated little significant effect of the $\mathrm{SiO}_{2} / \mathrm{Al}_{2} \mathrm{O}_{3}$ ratio for $\mathrm{T}-\mathrm{O}-\mathrm{Si}(\mathrm{T}=\mathrm{Si}$ or $\mathrm{Al}$ ) stretching vibration frequency. The bands with wavenumbers ranging from 800 to $600 \mathrm{~cm}^{-1}$ are mainly caused by Al-O stretching vibrations [33,34], and no significant difference was observed in the position of these bands. The absorption peak at $450 \mathrm{~cm}^{-1}$ is mainly attributed to the bending vibration of $\mathrm{Si}-\mathrm{O}-\mathrm{Si}$ and $\mathrm{Si}-\mathrm{O}-\mathrm{Al}$, and this weak peak is present in all samples at approximately the same position. We will discuss this below in the analysis of the ${ }^{29} \mathrm{Si}$ and ${ }^{27} \mathrm{Al}$ MAS-NMR results.

\section{4. ${ }^{29}$ Si and ${ }^{27}$ Al MAS-NMR Analysis}

Determination of the coordination number of aluminums with oxygen (four, five, or six) is possible using ${ }^{27} \mathrm{Al}$ MAS-NMR and ${ }^{29} \mathrm{Si}$ MAS-NMR methods to differentiate between the different $\mathrm{SiQ}^{\mathrm{n}}(\mathrm{mAl})$ structural units $[14,35]$.

The ${ }^{27} \mathrm{Al}$ MAS-NMR spectra of different samples were determined and are shown in Figure 4. For amorphous or semi-crystalline K-A-S-H products, obtained ${ }^{27} \mathrm{Al}$ MAS-NMR spectra can be split into two asymmetric lines with line shapes that are typical of $\mathrm{Al}$ in an amorphous environment (Figure $4 \mathrm{a}, \mathrm{b}$ ). The chemical shifts at $52 \mathrm{ppm}$ and $1 \mathrm{ppm}$ are respectively related to $\mathrm{Al}$ in tetrahedral (noted as $\mathrm{Al}$ IV) and hexahedral environments [36,37]. 


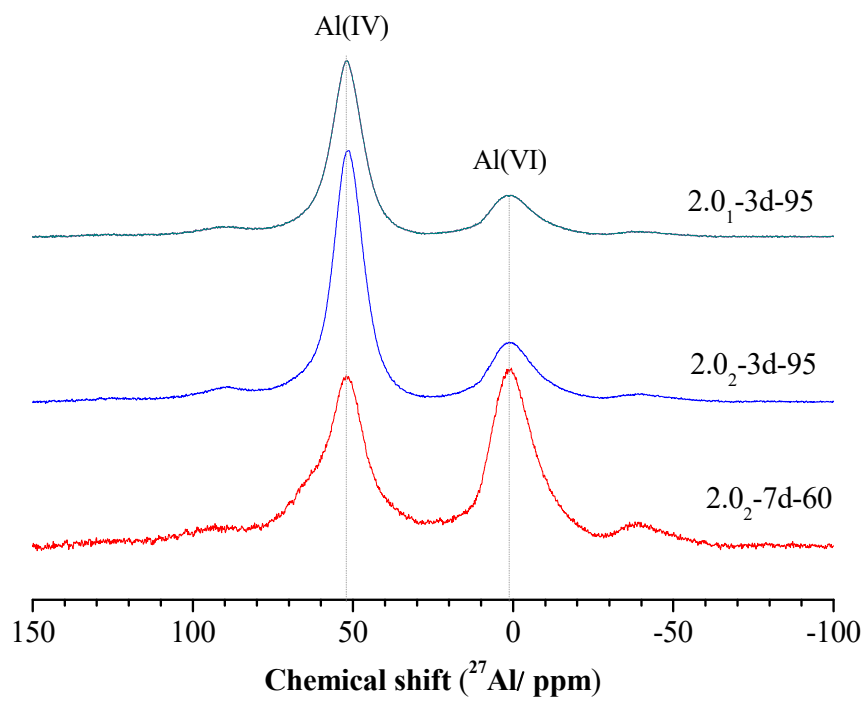

(a)

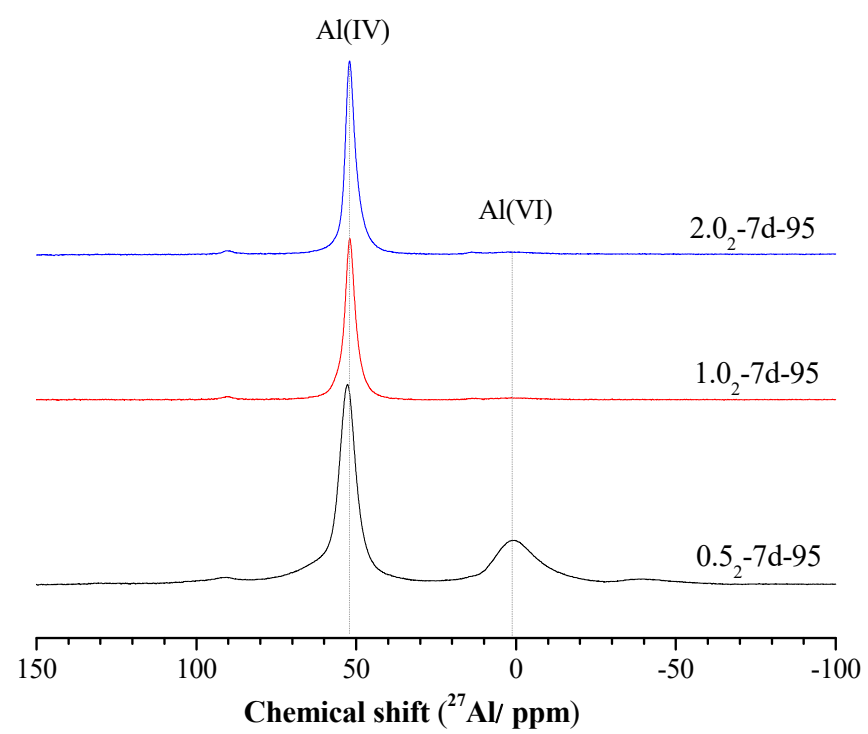

(b)

Figure 4. ${ }^{27} \mathrm{Al}$ MAS-NMR spectra of K-A-S-H samples (a) synthesized at different reaction temperatures and $\mathrm{SiO}_{2} / \mathrm{Al}_{2} \mathrm{O}_{3},\left(\right.$ b) synthesized using different $\mathrm{K}_{2} \mathrm{O} / \mathrm{SiO}_{2}$ ratios by reaction at $95^{\circ} \mathrm{C}$.

The variation of the $\mathrm{SiO}_{2} / \mathrm{Al}_{2} \mathrm{O}_{3}$ ratio did not significantly change the structure of the obtained K-A-S-H samples. However, increasing the curing temperature changed the process of aluminum coordination, from VI coordination to IV coordination, as shown in Figure 4a. By extending the age of curing, the weak peak at $1 \mathrm{ppm}$ slowly weakened until it disappeared, and the spectra for all the K-A-S-H samples after 3 days were much wider than those for the products cured for 7 days (see Figure 4). Additionally, it can be seen that the reduction of the $\mathrm{SiO}_{2} / \mathrm{Al}_{2} \mathrm{O}_{3}$ ratio favors the proportion of $\mathrm{Al}_{\mathrm{VI}}$ to the detriment of $\mathrm{Al}$ IV. A lower $\mathrm{K}_{2} \mathrm{O} / \mathrm{SiO}_{2}$ ratio may increases the percentage of $\mathrm{Al}_{\mathrm{VI}}$ involved in the sialate (-Si-O-Al-O-) tetrahedral crosslink [2]. Davidovits et al. [6] assume that $\mathrm{K}^{+}$compensates for a weak negative charge on $\mathrm{Al}_{\mathrm{IV}}$, and this is linked with a strong ionic bond within the $\mathrm{Si}-\mathrm{O}-\mathrm{Al}$ network. In summary, curing temperature and time showed a great effect on 
the morphology of ${ }^{27} \mathrm{Al}$ MAS-NMR spectra. The NMR spectroscopy shows an increased degree of polymerization with increased curing temperature and time for all $\mathrm{K}-\mathrm{A}-\mathrm{S}-\mathrm{H}$ samples [36].

The ${ }^{29} \mathrm{Si}$ MAS-NMR spectra of different samples are shown in Figure 5. The change of $\mathrm{SiO}_{2} / \mathrm{Al}_{2} \mathrm{O}_{3}$ ratio (with $\mathrm{K}_{2} \mathrm{O} / \mathrm{SiO}_{2}$ ratio kept constant) has little effect on the morphology of the ${ }^{29} \mathrm{Si}$ MAS-NMR spectra of the samples. When the curing temperature was increased by $95^{\circ} \mathrm{C}, \mathrm{Q}_{2}$ shifted to the negative direction, as shown in Figure 5a. As shown, there is only one main peak, with the first resonance at $-83 \mathrm{ppm}$ and the second at $-86 \mathrm{ppm}$. These peaks have been attributed to $\mathrm{Q}_{2}(1 \mathrm{Al})$ and $\mathrm{Q}_{2}(0 \mathrm{Al})$ units, respectively, indicating that most silicate tetrahedra are chain mid-members and $\mathrm{Al}$ substitution for $\mathrm{Si}$ has occurred in the silicate chains [36,37].

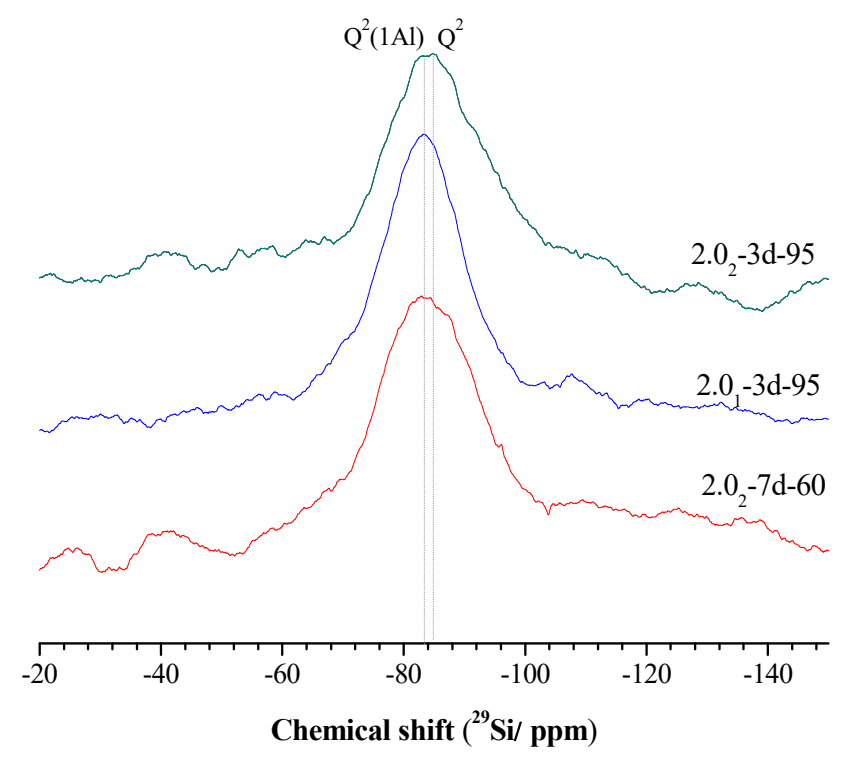

(a)

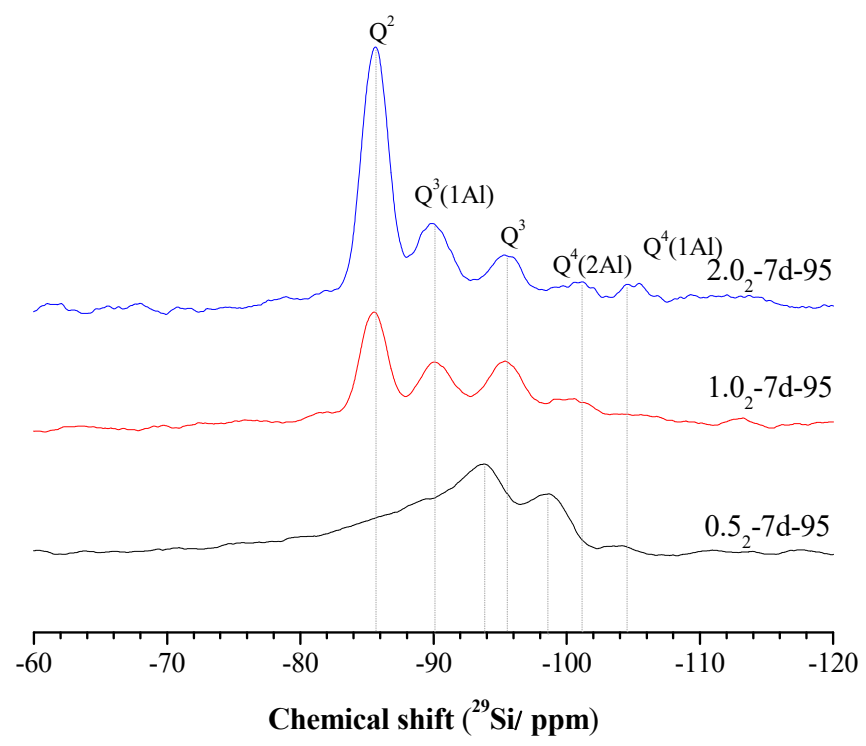

(b)

Figure 5. ${ }^{29} \mathrm{Si}$ MAS NMR spectra of K-A-S-H samples (a) synthesized at different reaction temperatures and different $\mathrm{SiO}_{2} / \mathrm{Al}_{2} \mathrm{O}_{3}$ ratios, and (b) synthesized using different $\mathrm{K}_{2} \mathrm{O} / \mathrm{SiO}_{2}$ ratios by reaction at $95^{\circ} \mathrm{C}$. 
After curing at $95{ }^{\circ} \mathrm{C}$ for 7 days, the ${ }^{29} \mathrm{Si}$ MAS-NMR chemical shift moved to a negative value, as shown in Figure $5 \mathrm{~b}$. This suggests a certain degree of structural rearrangement and greater cross-linking [2] in the K-A-S-H samples due to the formation of Si-O-Si bonds, and increased degree of polymerization with increased curing time and temperature. Under this condition, five characteristic peaks appear at a high $\mathrm{K}_{2} \mathrm{O} / \mathrm{SiO}_{2}$ ratio, with chemical shifts that correspond to $-85.5 \mathrm{ppm},-90 \mathrm{ppm}$, $-95.5 \mathrm{ppm},-101 \mathrm{ppm}$, and $-104.5 \mathrm{ppm}$. This is indicative of the formation of a highly polymerized, highly Al-substituted Si environment. A similar phenomenon was also observed in (C, N)-A-S-H gels $[2,24]$. The -85 ppm shift corresponds to $Q_{2}$ units. The chemical shifts at -90 ppm and -95 ppm correspond to $\mathrm{Q}_{3}$, and are consistent with chain branching sites $\left(\mathrm{Q}_{3}(1 \mathrm{Al})\right.$ units) and three-dimensional cross-linked sites $\left(\mathrm{Q}_{3}\right.$ units), both with substantial Al substitution for Si [14]. The chemical shifts of $-101 \mathrm{ppm}$ and $-104.5 \mathrm{ppm}$ were assigned to $\mathrm{Q}_{4}(2 \mathrm{Al})$ and $\mathrm{Q}_{4}(1 \mathrm{Al})$, respectively. The samples prepared with a high $\mathrm{K}_{2} \mathrm{O} / \mathrm{SiO}_{2}$ ratio are thus characterized as a highly polymerized structure composed principally of three-dimensionally cross-linked sites such as $\mathrm{Q}_{4}(2 \mathrm{Al})$ and $\mathrm{Q}_{4}(1 \mathrm{Al})$ units. As the $\mathrm{K}_{2} \mathrm{O} / \mathrm{SiO}_{2}$ ratio decreased, the two peaks slowly weakened in intensity. When the $\mathrm{K}_{2} \mathrm{O} / \mathrm{SiO}_{2}$ ratio decreased to 0.5 , the ${ }^{29} \mathrm{Si}$ MAS-NMR chemical shifted to a more negative value. The chemical shifts of -94 ppm and -99 ppm was respectively assigned to $\mathrm{Q}_{3}$ and $\mathrm{Q}_{4}(3 \mathrm{Al})$, and a weak peak at $104.5 \mathrm{ppm}$ was attributed to $\mathrm{Q}_{4}(1 \mathrm{Al})[14,38]$ (see Figure 5b). This indicated that at different $\mathrm{K}_{2} \mathrm{O} / \mathrm{SiO}_{2}$ ratios, K-A-S-H samples have different highly polymerized three-dimensional network zeolite structures after treatment at a certain curing temperature and time, with the higher $\mathrm{K}_{2} \mathrm{O} / \mathrm{SiO}_{2}$ ratio leading to a more developed framework. This finding is consistent with the XRD and ${ }^{27}$ Al MAS NMR analysis of these samples, and is further confirmed by visual observation in the SEM images described below.

In summary, amorphous or semi-crystalline K-A-S-H samples were formed from longer chains but the ${ }^{29} \mathrm{Si}$ MAS-NMR spectra showed mainly chain mid-member sites $\left[\mathrm{Q}_{2}\right.$ and $\left.\mathrm{Q}_{2}(1 \mathrm{Al})\right]$ [39]. In contrast, crystalline K-A-S-H samples mainly contain three-dimensional cross-linked sites $\left[\mathrm{Q}_{4}(2 \mathrm{Al})\right.$ and $\mathrm{Q}_{4}(1 \mathrm{Al})$ ], reflecting a highly polymerized structural aluminosilicate framework [40]. The above results are in agreement with the conclusions from the infrared and ${ }^{27}$ Al MAS-NMR spectroscopy results that increasing the curing temperature and time result in the continuous increase of the degree of polymerization of samples [36].

\subsection{SEM Analysis}

Figure 6 shows the scanning electron micrographs of the K-A-S-H samples. For curing temperature lower than $80{ }^{\circ} \mathrm{C}$, it can be clearly seen that the reaction products are mainly amorphous $\mathrm{K}-\mathrm{A}-\mathrm{S}-\mathrm{H}$ products. These products exhibit a loose flocculent form and are covered with fine powder (see Figure 6a), which is likely unreacted raw materials. When the curing temperature was increased to $95^{\circ} \mathrm{C}$, within 7 days of curing, most products remained in the irregularly flocculent form, with relatively loose filling, as shown in Figure 6b. However, we were unable to fully distinguish an amorphous gel. Thus, in Section 3.6, TEM image analysis was applied. At a reduced $\mathrm{SiO}_{2} / \mathrm{Al}_{2} \mathrm{O}_{3}$ ratio, a small amount of crystal phase particles appeared wrapped by amorphous gel particles or filled between particle gaps (see Figure 6f). In addition, for the products cured at $95{ }^{\circ} \mathrm{C}$ for 7 days, there were more obvious crystallized particles. At a $\mathrm{K}_{2} \mathrm{O} / \mathrm{SiO}_{2}$ ratio of 0.5 , the number of crystal particles increased, there were many thin strips of crystals that overlapped each other to form cluster-like crystals, and flocculent small particles were apparent on the surface (see Figure 6c). The Si:Al:K ratio of the product was 1.88:1:0.95, as determined via EDS, consistent with the formula for zeolite K-H synthesized by the sol-gel method and the previous measurement of 1.98:1:0.82 [18,19]. The image of the sample prepared with a $\mathrm{K}_{2} \mathrm{O} / \mathrm{SiO}_{2}$ ratio of 2.0 and cured at $95{ }^{\circ} \mathrm{C}$ is shown in Figure 6e. The crystal particles appeared fuller and denser, there were spherical crystals formed by the cross-linking of fibers and strips, and the crystallized particles were about $6-8 \mu \mathrm{m}$ in diameter. EDS analysis indicated a Si:Al:K ratio of the product that was close to the atomic ratio of $\mathrm{K}-\mathrm{G}$ zeolite [20]. However, at a $\mathrm{K}_{2} \mathrm{O} / \mathrm{SiO}_{2}$ ratio of 1.0, the crystal particles are interspersed and chimeric with many cluster-like crystals and spherical crystals, consistent with the XRD results that there are two crystal phases of zeolite K-H and K-G zeolite. Besides, 
the change of micromorphology observed in a zeolite (Figure $6 c-e$ ) may be attributed to the different polarizability of $\mathrm{K}^{+}$ions [41].

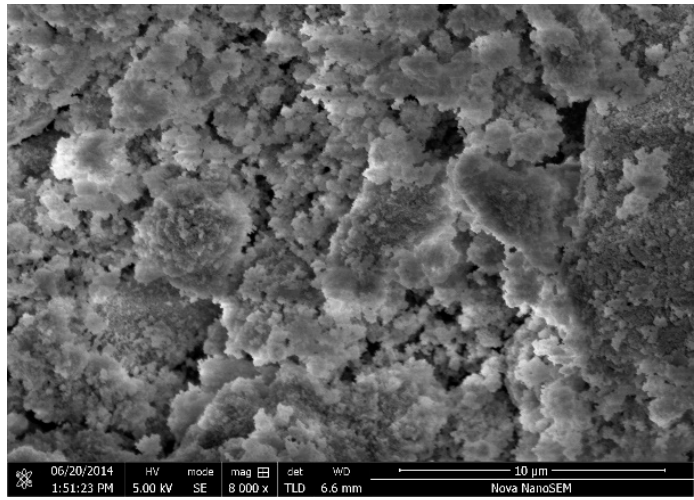

(a)

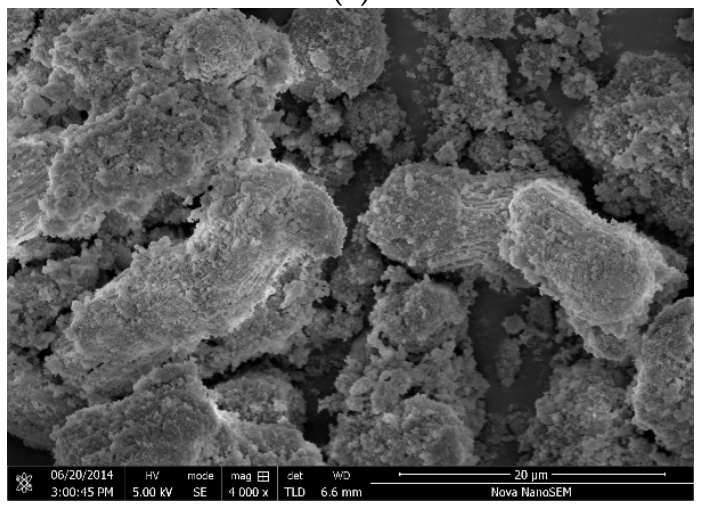

(c)

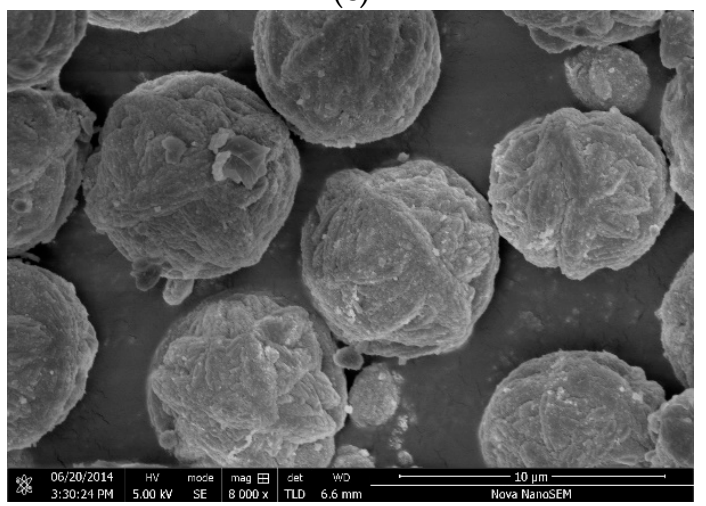

(e)

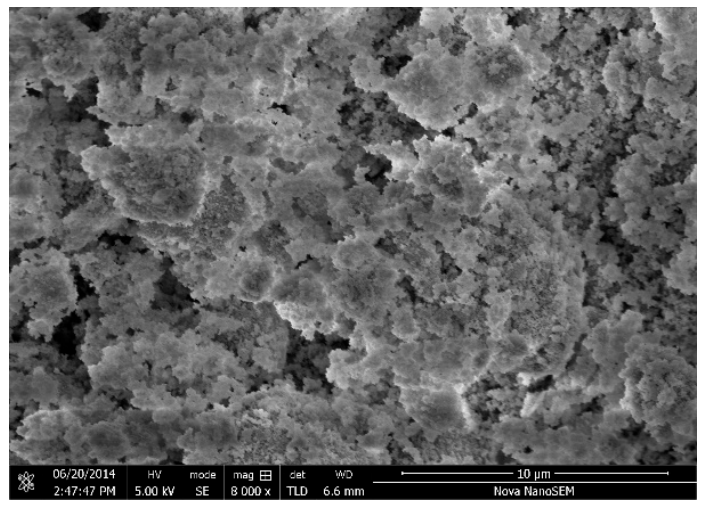

(b)

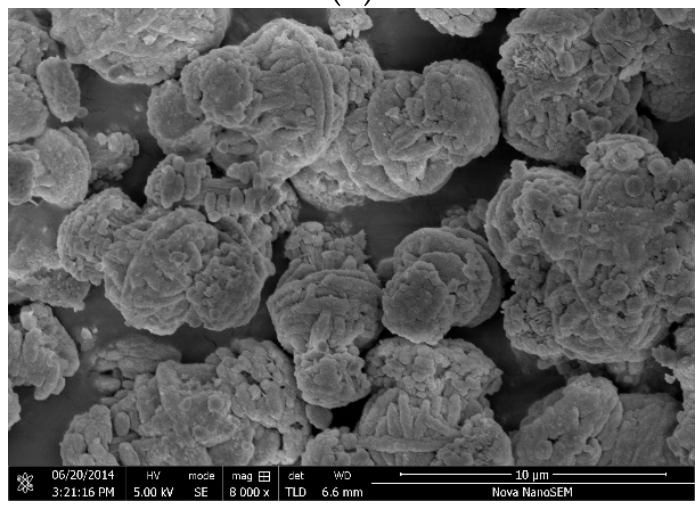

(d)

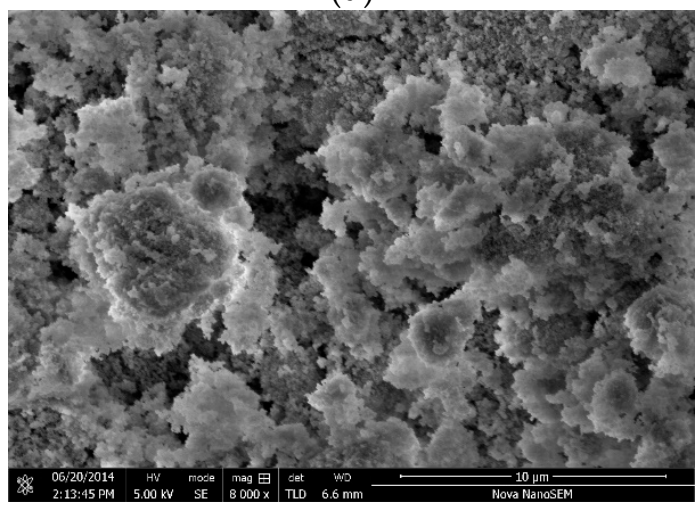

(f)

Figure 6. SEM images of K-A-S-H samples (a) K-A-S-H2.0 $2-3 d-60$, (b) K-A-S-H2.0 $2-3 d-95$, (c) K-A-S-H0.52-7d-95, (d) K-A-S-H1.02-7d-95, (e) K-A-S-H2.02-7d-95, and (f) K-A-S-H2.01-3d-95.

\subsection{TEM Analysis}

Figure 7a shows the TEM image of sample K-A-S-H2.0 $-7 \mathrm{~d}-60$, revealing mainly a loose flaky structure with aggregated strip particles and a porous and rough surface, surrounded by some spherical particles, which should be amorphous gels. Similar results were also reported by Pena et al. [42]. When the curing temperature was increased to $95^{\circ} \mathrm{C}$ for sample K-A-S-H 2.02-3d-95, as shown in Figure $7 \mathrm{~b}$, the products showed mainly irregular spherical particles of about 50-100 nm. The particles overlapped each other to form a small piece, different from sample K-A-S-H2.02-7d-60. Considered with the results of XRD analysis, in most cases, a significant amount of amorphous K-A-S-H gels was detected. For the sample cured for 7 days, K-A-S-H 0.52-7d-95 (see Figure 7c), there were no crystal grains, and thin, 
crumpled foils were observed [24], with some fibrous structures of about $200 \mathrm{~nm}$ polymerized together with the foils. Additionally, a small amount of flaky structure indicated the presence of the crystalline phase in the samples. For the sample prepared at a $\mathrm{K}_{2} \mathrm{O} / \mathrm{SiO}_{2}$ ratio of 2.0 at this curing temperature, as shown in Figure 7d, the layered sheet structure indicates the presence of another crystalline phase in the samples that is denser than that in the samples prepared at the low $\mathrm{K}_{2} \mathrm{O} / \mathrm{SiO}_{2}$ ratio.

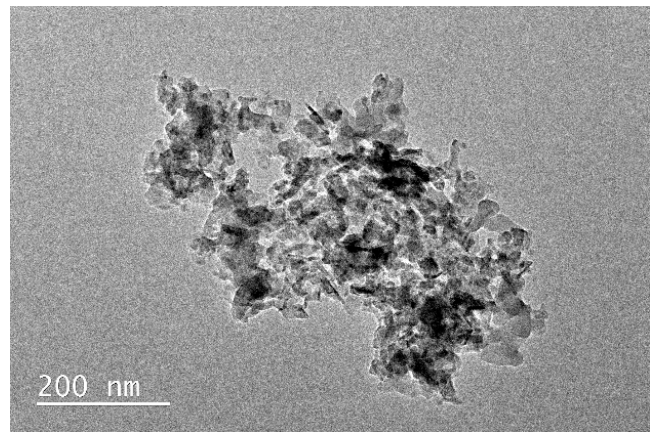

(a)

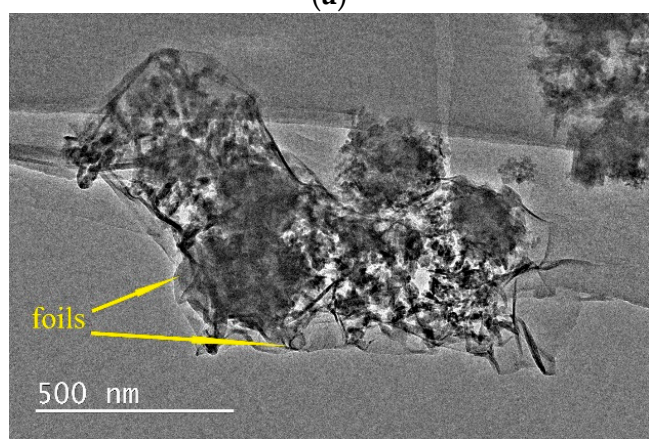

(c)

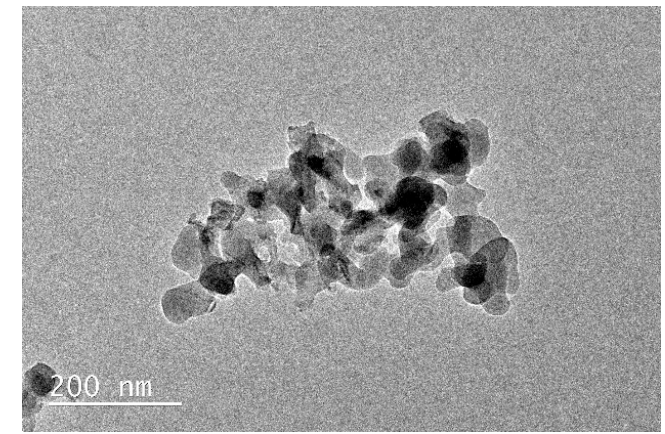

(b)

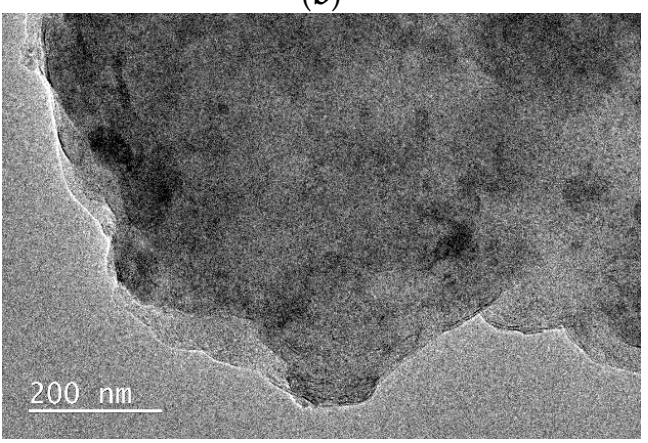

(d)

Figure 7. TEM images of K-A-S-H samples (a) K-A-S-H 2.02-7d-60, (b) K-A-S-H 2.0 2 -3d-95, (c) K-A-S-H $0.5_{2}-7 \mathrm{~d}-95$, (d) K-A-S-H 2.0 $2-7$ d-95.

\subsection{Particle Size Analysis}

The particle size distribution of the K-A-S-H samples are shown in Figure 8. Additionally, the BET nitrogen adsorption method was used to determine the specific surface area of the synthesized K-A-S-H samples, the isothermal adsorption curve and specific surface area data are shown in Figure 9 and Table 2, separately.

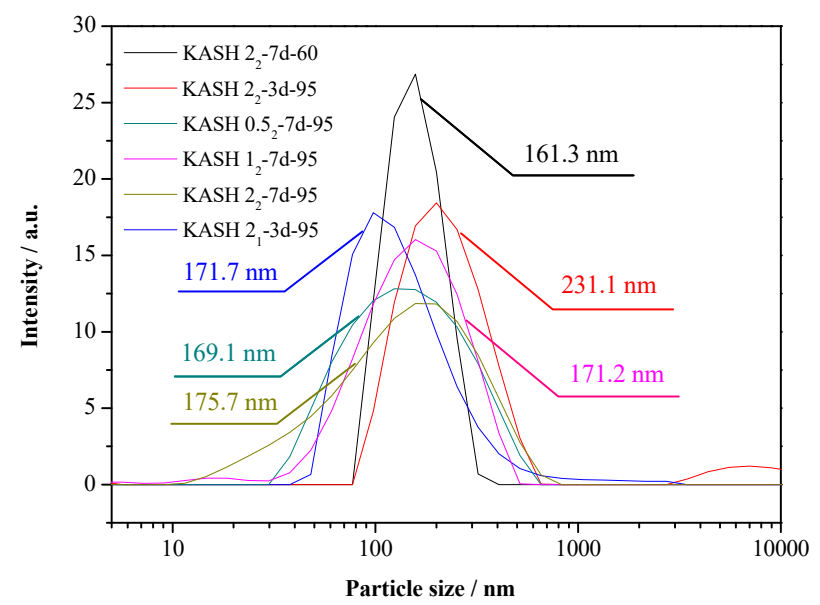

Figure 8. Particle size distribution of K-A-S-H samples. 


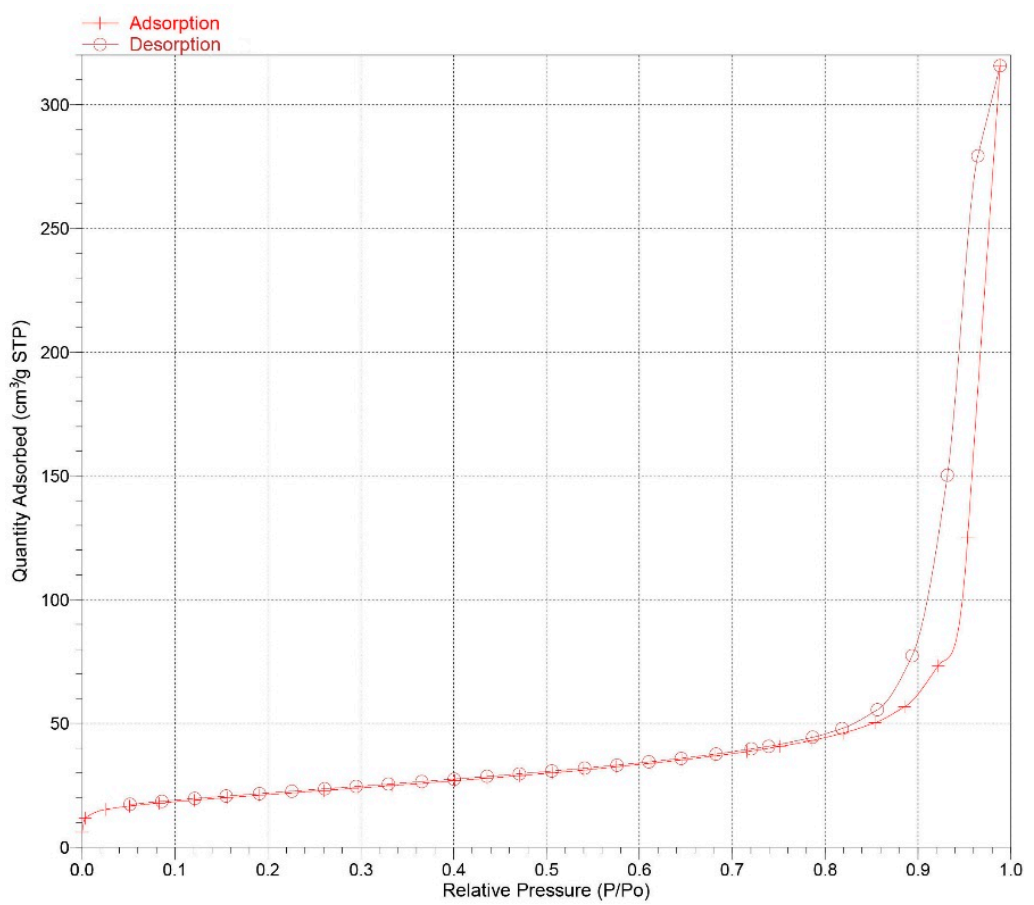

(a)

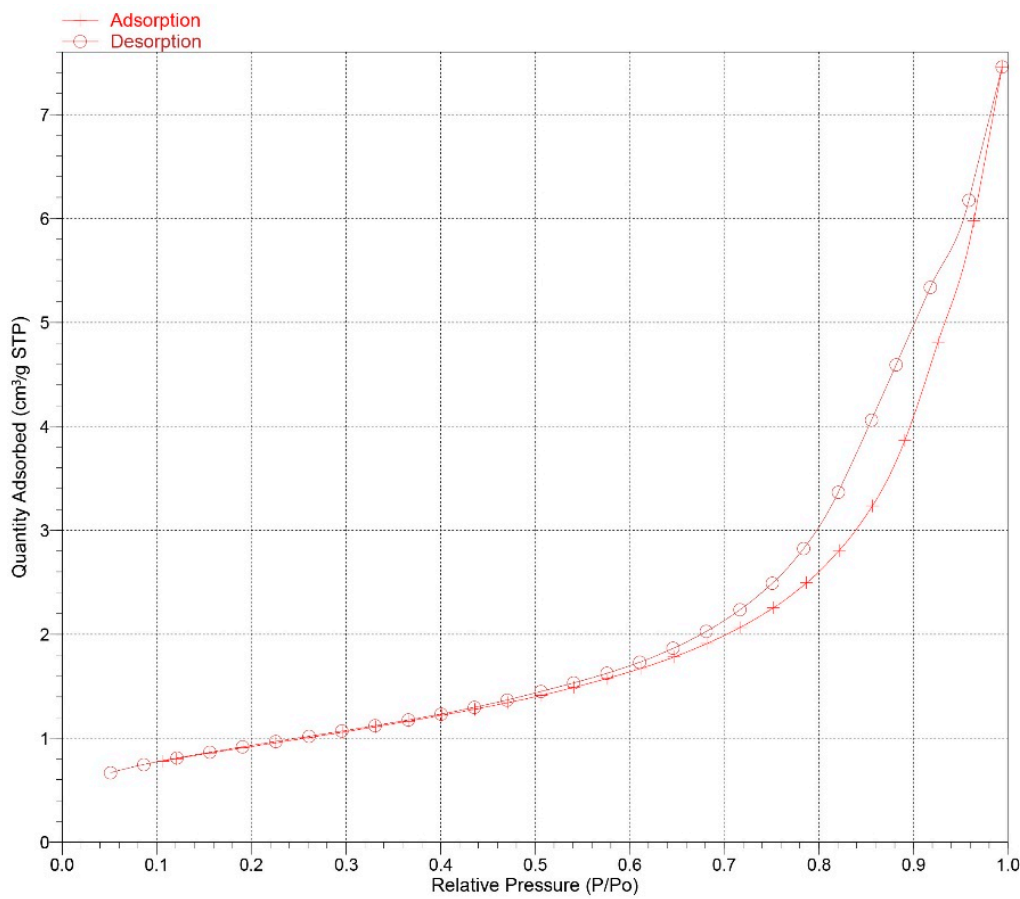

(b)

Figure 9. Isothermal adsorption curves of K-A-S-H samples (a) K-A-S-H 2.02-7d-60, (b) K-A-S-H $2.0_{2}-7 \mathrm{~d}-95$.

Table 2. BET specific surface area of K-A-S-H samples $\left(\mathrm{m}^{2} / \mathrm{g}\right)$.

\begin{tabular}{|c|c|c|c|c|c|}
\hline $2.0_{2}-7 d-60$ & $2.0_{1}-3 d-95$ & $2.0_{2}-3 d-95$ & $0.5_{2}-7 \mathrm{~d}-95$ & $1.0_{2}-7 d-95$ & $2.0_{2}-7 d-95$ \\
\hline 74.23 & 50.07 & 34.17 & 32.32 & 11.96 & 3.34 \\
\hline
\end{tabular}


The particle size distribution for each group of K-A-S-H samples was relatively stable, with a range of particle diameter of $100-300 \mathrm{~nm}$, and an average particle size of about $180 \mathrm{~nm}$. The results of particle size distribution analysis agree well with the results of sample agglomerated particle size obtained by TEM observation. The XRD, SEM, and TEM analysis of sample K-A-S-H2.02-7d-60 revealed an amorphous product, with the narrowness of the particle size distribution range likely related to the increase in the homogeneity of the raw material that did not completely react.

Figure 9 shows the isotherm adsorption curve of samples K-A-S-H 2.0 $0_{2}-7 \mathrm{~d}-60$ (amorphous) and K-A-S-H 2.0 2 -7d-95 (crystalline). In these two curves, there exist the hysteresis loops, which is thought to be caused by the detaining of the $\mathrm{N}_{2}$ gas molecule in gel micropores in the desorption process. It is found that the area between crystalline K-A-S-H sample hysteresis loops decreases, indicating that the number of nitrogen molecules entering the crystalline K-A-S-H sample's microstructural layer or gel micropores is less than that in the amorphous K-A-S-H sample. The calculated specific surface area data show a decrease in the BET specific surface area of the K-A-S-H samples resulting from an increase in the $\mathrm{SiO}_{2} / \mathrm{Al}_{2} \mathrm{O}_{3}$ or $\mathrm{K}_{2} \mathrm{O} / \mathrm{SiO}_{2}$ ratio. With extended curing temperature and the curing time, the specific surface area was significantly reduced. Together with the above results from XRD, TG, and SEM analysis that indicate a shift in product morphology from amorphous to semi-crystalline to crystalline, the structure of the K-A-S-H products shrinks to become more compact.

\section{Conclusions}

This study stoichiometrically synthesized K-A-S-H gels using a hydrothermal method. To probe the state of $\mathrm{Al}$ in the inner structure, conditions including $\mathrm{K} 2 \mathrm{O} / \mathrm{SiO}_{2}$ ratio, $\mathrm{SiO}_{2} / \mathrm{Al}_{2} \mathrm{O}_{3}$ ratio, curing temperature and curing time were varied and their effects on the resulting gels were investigated, and the following conclusions can be drawn:

(1) XRD results demonstrated the presence of amorphous K-A-S-H gel and two crystalline products of zeolite $\mathrm{K}-\mathrm{H}$ and $\mathrm{K}-\mathrm{G}$ zeolite. The high $\mathrm{K}_{2} \mathrm{O} / \mathrm{SiO}_{2}$ ratios led to the formation of $\mathrm{K}-\mathrm{G}$ zeolite, while zeolite $\mathrm{K}-\mathrm{H}$ in low ratios. For all samples cured at temperatures below $80^{\circ} \mathrm{C}$, the K-A-S-H products were completely amorphous. With increased curing temperature and time, the K-A-S-H products transformed from amorphous form to crystalline zeolite phase structure, with the reduced specific surface area. Combined with the TG results, the system contains more nonevaporated water or zeolite water for structural rearrangement, indicating a denser K-A-S-H product structure.

(2) The FTIR results show that an increase of the $\mathrm{K}_{2} \mathrm{O} / \mathrm{SiO}_{2}$ ratio led to an increase in the amount of non-bridged oxygen atoms in the structure, which in turn caused a shift in the $\mathrm{Si}-\mathrm{O}-\mathrm{T}$ absorption peak to a lower wavenumber and a slight decrease in the tetrahedral polymerization degree. The ${ }^{27} \mathrm{Al}$ and ${ }^{29} \mathrm{Si}$ MAS-NMR spectra reveal that the Al exhibits mainly VI and IV coordination, and the silicate network shows a progressive polymerization degree with increasing curing temperature and time. Additionally, the absorption band of the asymmetric stretching vibration of $\mathrm{T}-\mathrm{O}-\mathrm{Si}(\mathrm{T}=\mathrm{Si}$ or $\mathrm{Al})$ shifted to a lower wavenumber. The amorphous K-A-S-H gel contained $\mathrm{Q}_{2}$ and $\mathrm{Q}_{2}(1 \mathrm{Al})$ silicate groups arranged in a linear long-chain structure, with a crystalline state that was mainly composed of a three-dimensional crosslinking unit $\mathrm{Q}_{4}$. Different $\mathrm{K}_{2} \mathrm{O} / \mathrm{SiO}_{2}$ ratios result in different highly polymerized three-dimensional network-like zeolite structures in the crystalline K-A-S-H products.

(3) Amorphous K-A-S-H gels exhibited an irregular floc structure as observed under SEM. The crystallized product was interspersed with clusters of crystals and a large number of needle shape or filaments. The K-A-S-H gels observed under TEM showed random grain polymerization or a thin, wrinkled foil, which finally forms a short rod-like and flaky crystallized product. In addition, within a certain range, there was no significant effect of the $\mathrm{SiO}_{2} / \mathrm{Al}_{2} \mathrm{O}_{3}$ ratio on the structure of K-A-S-H products.

Low crystallinity K-A-S-H gels and zeolite crystalline powders were synthesized and the differences and similarities of their (micro) structures were analyzed. Our previous studies [3,7] have demonstrated the synthetic C-A-S-H gel can be regarded as a chemical intensification of the hardening effect in alkali-activated binders, which also refine the pore structures of the alkali-activated binders and 
provide a novel approach of alkali-activated binders shrinkage reduction at an early stage. Meanwhile, these gels and the hydration products of alkali-activated materials have similar composition and morphology. In view of this, the results found in this research further suggests this gel could be extended to low calcium systems, such as $\mathrm{K}(\mathrm{N})-\mathrm{A}-\mathrm{S}-\mathrm{H}\left(\mathrm{K}_{2} \mathrm{O}\left(\mathrm{Na}_{2} \mathrm{O}\right)-\mathrm{Al}_{2} \mathrm{O}_{3}-\mathrm{SiO}_{2}-\mathrm{H}_{2} \mathrm{O}\right)$, to be further applied to simulate and intensify the alkaline-activated binders. In this paper, it could be shown that the experimental design with a curing temperature of no more than $95^{\circ} \mathrm{C}$ and a curing time of about 3 days is suitable for the synthesis of similar potential gels.

Author Contributions: B.L. did the experiments, data analysis, and wrote part of this paper. Y.F. provided the original ideas and did data analysis. C.Z. wrote part of this paper. K.Z. and L.S. wrote part of this paper and participated in the revision work. W.L. provided the original ideas. F.X. provided the original ideas. D.L. provided the original ideas. All authors have read and agreed to the published version of the manuscript.

Funding: This research was funded by Chinese National Natural Science Foundation [Project No. 51872137]; Chinese National Natural Science Foundation [Project No. 51508337]; Chinese National Natural Science Foundation [Project No. 51538007]; Natural Science Foundation of SZU [Project No. 827000091] and Natural Science Foundation of Guangdong Province [Project No. 2019A1515012014].

Conflicts of Interest: The authors declare no conflict of interest.

\section{References}

1. Gartner, E.M.; Macphee, D.E. A physico-chemical basis for novel cementitious binders. Cem. Concr. Res. 2011, 41, 736-749. [CrossRef]

2. Walkley, B.; San, N.R.; Sani, M.A.; Gehman, J.D.; van Deventer, J.S.; Provis, J.L. Phase evolution of $\mathrm{Na}_{2} \mathrm{O}-\mathrm{Al}_{2} \mathrm{O}_{3}-\mathrm{SiO}_{2}-\mathrm{H}_{2} \mathrm{O}$ gels in synthetic aluminosilicate binders. Dalton Trans. 2016, 45, 5521-5535. [CrossRef] [PubMed]

3. Liu, B.; Yang, J.; Li, D.; Xing, F.; Fang, Y. Effect of a Synthetic Nano-CaO- $\mathrm{Al}_{2} \mathrm{O}_{3}-\mathrm{SiO}_{2}-\mathrm{H}_{2} \mathrm{O}$ Gel on the Early-Stage Shrinkage Performance of Alkali-Activated Slag Mortars. Materials 2018, 11, 1128. [CrossRef] [PubMed]

4. Yang, J.; Li, D.; Fang, Y. Synthesis of Nanoscale $\mathrm{CaO}-\mathrm{Al}_{2} \mathrm{O}_{3}-\mathrm{SiO}_{2}-\mathrm{H}_{2} \mathrm{O}$ and $\mathrm{Na}_{2} \mathrm{O}-\mathrm{Al}_{2} \mathrm{O}_{3}-\mathrm{SiO}_{2}-\mathrm{H}_{2} \mathrm{O}$ Using the Hydrothermal Method and Their Characterization. Materials 2017, 10, 695. [CrossRef] [PubMed]

5. Provis, J.L. Alkali-activated materials. Cem. Concr. Res. 2018, 114, 40-48. [CrossRef]

6. Škvára, F.; Šmilauer, V.; Hiaváek, P.; Kopecky, L.; Cílová, Z. A weak alkali bond in (N, K)-A-S-H gels: Evidence from leaching and modeling. Ceramics-Silikáty 2012, 56, 374-382.

7. Yang, J.; Li, D.; Fang, Y. Effect of synthetic $\mathrm{CaO}-\mathrm{Al}_{2} \mathrm{O}_{3}-\mathrm{SiO}_{2}-\mathrm{H}_{2} \mathrm{O}$ on the early-stage performance of alkali-activated slag. Constr. Build. Mater. 2018, 167, 65-72. [CrossRef]

8. Krivenko, P.V.; Kovalchuk, G.Y. Directed synthesis of alkaline aluminosilicate minerals in a geocement matrix. J. Mater. Sci. 2007, 42, 2944-2952. [CrossRef]

9. Krivenko, P.V. Status and Prospects of Research and Application of Alkali-Activated Materials. Adv. Sci. Technol. 2010, 69, 1-10. [CrossRef]

10. Bell, J.L.; Sarin, P.; Provis, J.L.; Haggerty, R.P.; Driemeyer, P.E.; Chupas, P.J.; van Deventer, J.S.J.; Kriven, W.M. Atomic Structure of a Cesium Aluminosilicate Geopolymer: A Pair Distribution Function Study. Chem. Mater. 2010, 20, 4768-4776. [CrossRef]

11. White, C.E.; Provis, J.L.; Proffen, T.; Van Deventer, J.S.J. The Effects of Temperature on the Local Structure of Metakaolin-Based Geopolymer Binder: A Neutron Pair Distribution Function Investigation. J. Am. Ceram. Soc. 2010, 93, 3486-3492. [CrossRef]

12. Fernández-Jiménez, A.; Vallepu, R.; Terai, T.; Palomo, A.; Ikeda, K. Synthesis and thermal behavior of different aluminosilicate gels. J. Non-Cryst. Solids 2006, 352, 2061-2066. [CrossRef]

13. Rovnaník, P. Effect of curing temperature on the development of hard structure of metakaolin-based geopolymer. Constr. Build. Mater. 2010, 24, 1176-1183. [CrossRef]

14. Lecomte, I.; Henrist, C.; Liégeois, M.; Maseri, F.; Rulmont, A.; Cloots, R. (Micro)-structural comparison between geopolymers, alkali-activated slag cement and Portland cement. J. Eur. Ceram. Soc. 2006, 26, 3789-3797. [CrossRef]

15. Bach, T.T.H.; Chabas, E.; Pochard, I.; Coumes, C.C.D.; Haas, J.; Frizon, F.; Nonat, A. Retention of alkali ions by hydrated low-pH cements: Mechanism and $\mathrm{Na}^{+} / \mathrm{K}^{+}{ }^{+}$selectivity. Cem. Concr. Res. 2013, 51, 14-21. [CrossRef] 
16. Bach, T.T.H.; Coumes, C.C.D.; Pochard, I.; Mercier, C.; Revel, B.; Nonat, A. Influence of temperature on the hydration products of low pH cements. Cem. Concr. Res. 2012, 42, 805-817. [CrossRef]

17. SchmelZ, E.C.; Stizbbins, J.F. Glass: gel synthesis of an albite $\left(\mathrm{NaAlSi}_{3} \mathrm{O}_{8}\right)$ glass:An NMR analysis. Geohim. Cosmochim. Acta 1993, 57, 3949-3960. [CrossRef]

18. Sathupunya, M.; Gulari, E.; Jamieson, A.; Wongkasemjit, S. Microwave-assisted preparation of zeolite K-H from alumatrane and silatrane. Microporous Mesoporous Mater. 2004, 69, 157-164. [CrossRef]

19. Liu, D.; Yuan, W.; Deng, L.; Yu, W.; Sun, H.; Yuan, P. Preparation of porous diatomite-templated carbons with large adsorption capacity and mesoporous zeolite K-H as a byproduct. J. Colloid Interface Sci. 2014, 424, 22-26. [CrossRef]

20. Yuan, J.; Yang, J.; Ma, H.; Chang, Q. Preparation of Zeolite F as Slow Release Fertilizers from K-Feldspar Powder. Chemistryselect 2017, 2, 10722-10726. [CrossRef]

21. Provis, J.L.; Duxson, P.; Lukey, G.C.; van Deventer, J.S.J. Statistical Thermodynamic Model for Si/Al Ordering in Amorphous Aluminosilicates. Chem. Mater. 2005, 17, 2976-2986. [CrossRef]

22. Sun, G.K.; Young, J.F.; Kirkpatrick, R.J. The role of Al in C-S-H: NMR, XRD, and compositional results for precipitated samples. Cem. Concr. Res. 2006, 36, 18-29. [CrossRef]

23. Garcia-Lodeiro, I.; Palomo, A.; Fernández-Jiménez, A.; Macphee, D.E. Compatibility studies between $\mathrm{N}-\mathrm{A}-\mathrm{S}-\mathrm{H}$ and C-A-S-H gels. Study in the ternary diagram $\mathrm{Na}_{2} \mathrm{O}-\mathrm{CaO}-\mathrm{Al}_{2} \mathrm{O}_{3}-\mathrm{SiO}_{2}-\mathrm{H}_{2} \mathrm{O}$. Cem. Concr. Res. 2011, 41, 923-931. [CrossRef]

24. Kapeluszna, E.; Kotwica, Ł.; Różycka, A.; Gołek, Ł. Incorporation of Al in C-A-S-H gels with various Ca/Si and Al/Si ratio: Microstructural and structural characteristics with DTA/TG, XRD, FTIR and TEM analysis. Constr. Build. Mater. 2017, 155, 643-653. [CrossRef]

25. Thomas, J.J.; FitzGerald, S.A.; Neumann, D.A.; Livingston, R.A. State of Water in Hydrating Tricalcium Silicate and Portland Cement Pastes as Measured by Quasi-Elastic Neutron Scattering. J. Am. Ceram. Soc. 2001, 84, 1811-1816. [CrossRef]

26. Kupwade-Patil, K.; Tyagi, M.; Brown, C.M.; Büyüköztürk, O. Water dynamics in cement paste at early age prepared with pozzolanic volcanic ash and Ordinary Portland Cement using quasielastic neutron scattering. Cem. Concr. Res. 2016, 86, 55-62. [CrossRef]

27. García-Lodeiro, I.; Fernández-Jiménez, A.; Palomo, A.; Macphee, D.E. Effect of Calcium Additions on N-A-S-H Cementitious Gels. J. Am. Ceram. Soc. 2010, 93, 1934-1940. [CrossRef]

28. García-Lodeiro, I.; Fernández-Jiménez, A.; Blanco, M.T.; Palomo, A. FTIR study of the sol-gel synthesis of cementitious gels: C-S-H and N-A-S-H. J. Sol-Gel Sci. Technol. 2008, 45, 63-72. [CrossRef]

29. García Lodeiro, I.; Macphee, D.E.; Palomo, A.; Fernández-Jiménez, A. Effect of alkalis on fresh C-S-H gels, FTIR analysis. Cem. Concr. Res. 2009, 39, 147-153. [CrossRef]

30. Mostafa, N.Y.; Shaltout, A.A.; Omar, H.; Abo-El-Enein, S.A. Hydrothermal synthesis and characterization of aluminium and sulfate substituted 1.1nm tobermorites. J. Alloys Compd. 2009, 467, 332-337. [CrossRef]

31. Walkley, B.; San Nicolas, R.; Sani, M.; Rees, G.J.; Hanna, J.V.; van Deventer, J.S.J.; Provis, J.L. Phase evolution of C-(N)-A-S-H/N-A-S-H gel blends investigated via alkali-activation of synthetic calcium aluminosilicate precursors. Cem. Concr. Res. 2016, 89, 120-135. [CrossRef]

32. García Lodeiro, I.; Fernández-Jimenez, A.; Palomo, A.; Macphee, D.E. Effect on fresh C-S-H gels of the simultaneous addition of alkali and aluminium. Cem. Concr. Res. 2010, 40, 27-32. [CrossRef]

33. Škvára, F.; Kopecký, L.; Šmilauer, V.; Bittnar, Z. Material and structural characterization of alkali activated low-calcium brown coal fly ash. J. Hazard. Mater. 2009, 168, 711-720. [CrossRef] [PubMed]

34. Lee, W.K.W.; van Deventer, J.S.J. Use of Infrared Spectroscopy to Study Geopolymerization of Heterogeneous Amorphous Aluminosilicates. Langmuir 2003, 19, 8726-8734. [CrossRef]

35. Rowles, M.R.; Hanna, J.V.; Pike, K.J.; Smith, M.E. O'Connor BH, ${ }^{29} \mathrm{Si}^{27}{ }^{27} \mathrm{Al},{ }^{1} \mathrm{H}$ and ${ }^{23} \mathrm{Na}$ MAS NMR Study of the Bonding Character in Aluminosilicate Inorganic Polymers. Appl. Magn. Reson. 2007, 32, 663-689. [CrossRef]

36. Oudadesse, H.; Derrien, A.C.; Lefloch, M.; Davidovits, J. MAS-NMR studies of geopolymers heat-treated for applications in biomaterials field. J. Mater. Sci. 2010, 42, 3092-3098. [CrossRef]

37. Guo, X.; Meng, F.; Shi, H. Microstructure and characterization of hydrothermal synthesis of Al-substituted tobermorite. Constr. Build. Mater. 2017, 133, 253-260. [CrossRef]

38. Knight, C.T.G.; Balec, R.J.; Kinrade, S.D. The Structure of Silicate Anions in Aqueous Alkaline Solutions. Angew. Chem. Int. Ed. 2007, 46, 8148-8152. [CrossRef] 
39. Duxson, P.; Provis, J.L.; Lukey, G.C.; Mallicoat, S.W.; Kriven, W.M.; van Deventer, J.S.J. Understanding the relationship between geopolymer composition, microstructure and mechanical properties. Colloids Surf. A Physicochem. Eng. Asp. 2005, 269, 47-58. [CrossRef]

40. Duxson, P.; Provis, J.L.; Lukey, G.C.; Separovic, F.; van Deventer, J.S.J. 29Si NMR Study of Structural Ordering in Aluminosilicate Geopolymer Gels. Langmuir 2005, 21, 3028-3036. [CrossRef]

41. Marakatti, V.S.; Rao, P.V.C.; Choudary, N.V.; Ganesh, G.S.; Shah, G.; Maradur, S.P.; Halgeri, A.B.; Shanbhag, G.V.; Ravishankar, R. Influence of Alkaline Earth Cation Exchanged X-Zeolites Towards Ortho-Selectivity in Alkylation of Aromatics: Hard-Soft-Acid-Base Concept. Adv. Porous Mater. 2014, 2, 221-229. [CrossRef]

42. Pena, P.; Rivas Mercury, J.M.; de Aza, A.H.; Turrillas, X.; Sobrados, I.; Sanz, J. Solid-state ${ }^{27} \mathrm{Al}$ and ${ }^{29} \mathrm{Si}$ NMR characterization of hydrates formed in calcium aluminate-silica fume mixtures. J. Solid State Chem. 2008, 181, 1744-1752. [CrossRef]

(C) 2019 by the authors. Licensee MDPI, Basel, Switzerland. This article is an open access article distributed under the terms and conditions of the Creative Commons Attribution (CC BY) license (http://creativecommons.org/licenses/by/4.0/). 